\title{
Needle Blight of Taxodium mucronatum in the Philippines
}

\author{
Takao KOBAYASHI* \\ 小林龺夫*：フィリピンに拈るメキシュラクウショウ赤枯病
}

On September lst of 1977, an occurrence of a severe needle blight disease was found on several potted seedlings of Taxodium mucronatum Ten. which were introduced from the United States in the previous year to Pacdal Forest Nursery, Luzon, Philippines. Many fruiting bodies of a species of Cercospora were observed on the blighted needles. Their morphological characteristics seemed to be very similar to those of Cercospora sequoiae Ell. et Ev., which has been known in Japan as the needle blight fungus of Cryptomeria japonica D. Don, Sequoiadendron giganteum Buchh. and Taxodium distichum Richard.

It is the purpose of this paper to confirm the similarity between two Cercosporae causing the needle blight of Taxodium in the Philippines and of Cryptomeria in Japan, and to give an additional evidence to the assumption that the needle blight fungus of Cryptomeria was introduced from the foreign country in the beginning of the 20th century.

Symtoms and signs Small and pale brown spots appear on needles, then spots become larger and brownish, usually extending the entire length of the needles. Affected needles are often curled and gradually defoliate. The disease attacks not only the needles but also current year's green shoots. Severely infected trees lose almost all of their needles and only a few green needles survive on the tops of current shoots. New needles are sprouted from the adventitious buds formed on bared shoots and twigs. They are again affected and the diseased needles gradually defoliate. On the blighted needles many powdery masses, greenish brown to grayish brown in color, are produced.

Morphology Stroma acicola, amphigenous, scattered, composed of pseudoparenchymatous cells, olive brown to dark brown or dark greenish brown, $40-90 \mu \mathrm{m}$ in diam.; conidiophores brown to olive brown, paler toward the top, simple, curved or zigzag-shape, non- or 1-septate, $38-58 \times 3-5 \mu \mathrm{m}$; conidia pale olive brown to olive brown or greenish brown, obclavate, straight or curved, 2-8-septate, constricted at septa in aged stage, 38-80x 4.5-7 $\mu \mathrm{m}$, with many minute warts on the surface. (Fig. 1).

The fungus has unique conidia having two noticeable characters, one being the marked constriction and the dark coloration in aged conidia and the other being many minute warts on the surface of conidia. Among the genus Cercospora, a few species has been known in having either the dark conidia or warted conidia. Cercospora sequoiae is only species having dark conidia with many warts. It has been known to cause the needle blight of several conifers in Japan, Formosa and the United States ${ }^{1,2,3,4,5,6)}$. Morphologically, the

\footnotetext{
* Forestry and Forest Products Research Institute, P. O. Box 16, Tsukuba-Norin-Kenkyu-Danchi, Ibaraki 305, Japan 農林水産省林菜試験場

1) Hodges, C.S. (1962). Mycologia 54:62-69. 2 2) Ito. K., Shibukawa. K. and Kobayashi, T. (1952). Bull. Gov. For. Exp. Sta. 52: 79-152. 3) Ito, K., Shibukawa, K. and Kobayashi, T. (1958). J. Jap. For. Soc. 40 (9): $407-410$. 4) Ito. K., Kobayashi, T. and Shibukawa, K. (1967). Bull. Gov. For. Exp. Sta. 204: 73-90. 5) Sawada, K. (1928). Rept. Dept. Agr., Gov'nt. Res. Inst. Formosa 35: 107-108. 6) Zinno. Y. (1969). J. Jap. For. Soc. 51 (7): $183-187$.
} 
Philippine fungus was quite identical with Cercospora sequoiae. (Table 1).

Isolation Monoconidial isolation of the fungus produced very similar colonies to those of the Cercospora sequoiae originated from Cryptomeria japonica. Colonies grew 20 to 30 $\mathrm{mm}$ in diam. after one month of incubation at $25 \mathrm{C}$. They are dark green to blackish green and are covered with white to grayish white aerial mycelia. They did not produce any conidia on agar media, but abundant conidia were produced on sclerotial bodies obtained by Zinno's procedure ${ }^{7 \text {. }}$.

Pathogenicity Mycelial suspensions were used for inoculum in two inoculation experiments conducted in 1978, and conidial suspensions for 1979's test. Inoculum suspensions were sprayed on one-year-old and 2-year-old seedlings of Cryptomeria japonica. Inoculated seedlings were kept under moist condition for 48 hours at 20-30 C. Results of the inoculation tests are given in Table 2. Needle blight developed after 30 days of incubation and severe disease development as observed in the field was recorded after 2 months of incubation in 1979's test. No difference was recognized between two isolates originated from

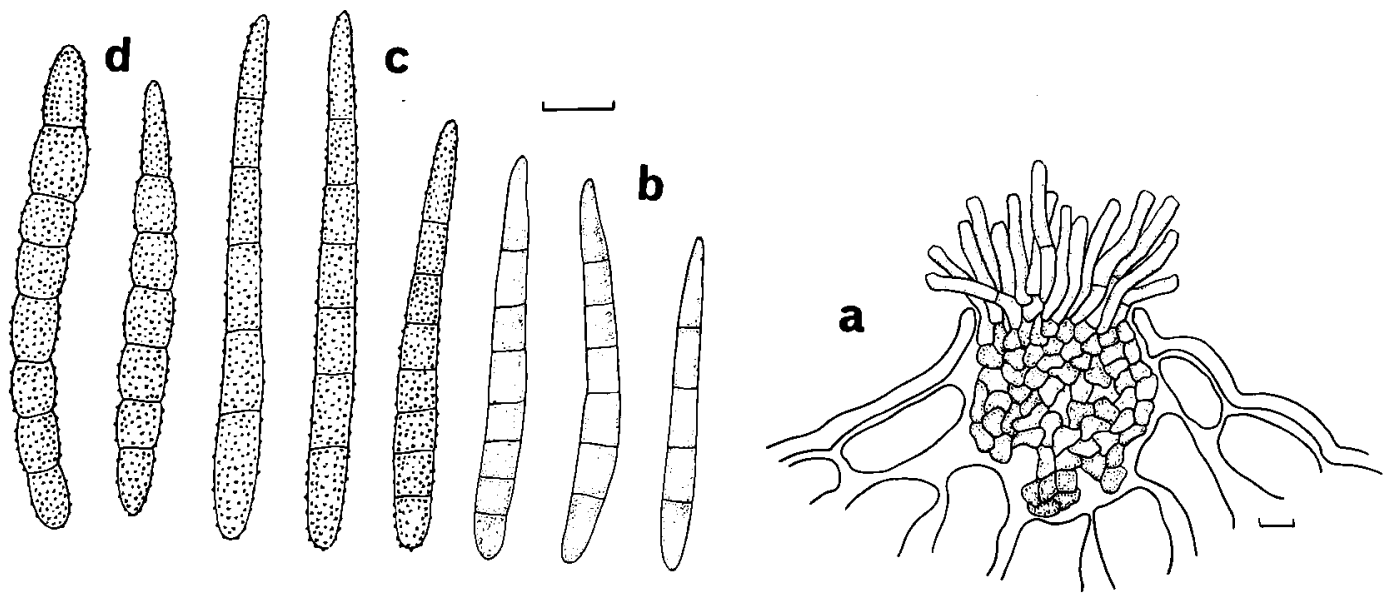

Fig. 1. Cercospora sequoiae Ell. et Ev, on Taxodium mucronatum a : Stroma and conidiophores, b: Young conidia without wart, c: Mature conidia with warts, d: Aged conidia with constriction (scales : $10 \mu \mathrm{m}$ )

Table 1. Dimensions of Cercosporae on Taxodium, Sequoiadendron and Cryptomeria

\begin{tabular}{c|c|c|c|c}
\hline \multicolumn{1}{c|}{ Fungus (Locality) } & Host & $\begin{array}{c}\text { Conidiophore } \\
(\mu \mathrm{m})\end{array}$ & \multicolumn{2}{|c}{ Conidium } \\
\cline { 1 - 5 } & & Size $(\mu \mathrm{m})$ & Septum \\
\hline Cercospora sp. (Philippines) & $\begin{array}{l}\text { Taxodium mucronatum } \\
\text { Cryptomeria japonica* }\end{array}$ & $\begin{array}{l}38-50 \times 3-5 \\
40-58 \times 4-5\end{array}$ & $\begin{array}{l}45-73 \times 4.5-7 \\
38-80 \times 4.5-6.5\end{array}$ & $2-6$ a) \\
\hline \multirow{2}{*}{ Cercospara sequoiae (Japan) } & Cryptomeria japonica* & $30-55 \times 4-5$ & $38-80 \times 4.5-6.5$ & $2-5$ a) \\
& Cryptomeria japonica & $40-80 \times 4-6$ & $30-85 \times 5-9$ & $2-7$ b) \\
& Sequoiadendron giganteum & $55-70 \times 5-8$ & $37-53 \times 5-7$ & $3-5 \mathrm{c})$ \\
& Taxodium distichum & $31-88 \times 4-5$ & $39-88 \times 5-7$ & $3-10 \mathrm{~d})$ \\
\hline
\end{tabular}

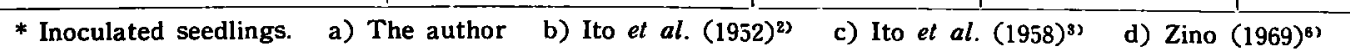

7) Zinno. Y. (1979). Bull. For. \& For. Prod. Res. Inst. 302: 1-77. 
Table 2. Pathogenicity of Taxodium- and Cryptomeria-isolates to Cryptomeria-seedlings

\begin{tabular}{|c|c|c|c|c|c|c|}
\hline $\begin{array}{l}\text { Inoculum isolate } \\
\text { Experiment }\end{array}$ & \multicolumn{2}{|c|}{$\mathrm{CC}-136^{\mathrm{a})}$} & \multicolumn{2}{|c|}{$\mathrm{CC}-\mathbf{8 5}^{\mathrm{b})}$} & \multicolumn{2}{|c|}{ Control } \\
\hline I (VIII- 7, 1978) & $3 / 3^{e)}$ & $+d)$ & $3 / 3$ & + & $0 / 2$ & - \\
\hline II (VIII-13, 1978) & $3 / 3$ & + & $3 / 3$ & + & $0 / 2$ & - \\
\hline III $($ IX $-8,1979)$ & $4 / 4$ & HH & $4 / 4$ & H & $0 / 4$ & - \\
\hline
\end{tabular}

a) From Taxodium mucronatum of the Philippines.

b) From Cryptomeria japonica of Japan.

c) Denominator : number of inoculated seedlings. Numerator : number of positive infection.

d) Degree of disease development and production of fruiting bodies, + : slight, $\mathrm{W}$ : heavy or numerous.

Taxodium (CC-136) and from Cryptomeria (CC-85), not only in their pathogenicity to Cryptomeria-seedlings but also in the dimensions of their fruiting bodies produced on the inoculated needles (Table 1).

Identification The Cercospora causing the needle blight of Taxodium mucronatum in the Philippines was identified with $C$. sequoiae Ell. et Ev. on the bases of quite identity to the latter in its morphological characteristics and pathogenicity to Cryptomeria-seedlings as shown in Tables 1 and 2 .

Discussion The needle blight fungus of Taxodium mucronatum in the Philippines was identified as Cercospora sequoiae. It was introduced from the United States with its host plants Taxodium to the Philippines. On the other hand, a species of Cercospora has been well known in Japan as the most virulent pathogen to Cryptomeria japonica. It causes severe needle blight of the seedlings. No record of the disease occurrence has been found before the 20th century, nevertheless the cultivation of Cryptomeria-seedlings from seeds has been continued as early as the 16 th century ${ }^{4,8,9)}$. The causal fungus was first named Cercospora cryptomeriae Shirai ${ }^{10)}$ as indigenous to Japan, but it was later proved to be the same as American species, Cercospora sequoiae, through the comparative cultural, morphological and etiological studies with Japanese and American specimens and isolates ${ }^{4}$.

From these facts, Ito et $a .^{4)}$ assumably concluded that Cercospora sequoiae had been introduced from the United States to Japan at the beginning of the 20th century with the susceptible exotic conifers, and that it soon became prevalent on Japanese susceptible host, Cryptomeria japonica. Their assumption was supported here by an additional fact that Cercospora sequoiae is introducing at present from the United States to the Philippines with its susceptible host, Taxodium mucronatum.

Acknowledgement The author expresses his heartfelt thanks to the Staff members of RP (Republic of the Philippines)-Japan Afforestation Project in the Pantabangan area, for their courtesy to give the author the chance to observe the forest diseases in the Philippines during the stay there as technical consultant.

(Received January 7, 1980)

8) Ito, K. (1967). For. Prot. News 16(6): 122-126.

9) Ito, K. (1969). P1. Prot. 23(5): 207-210.

10) Kitajima, K. (1916). Bot. Mag. 30: 411-414. 


\section{Explanation of Plate}

A : Needle blight of Taxodium mucronaum caused by Cercospora sequoiae.

B : Diseased neebles of Taxodium mucronatum caused by Cercospora sequoiae.

C: Conidium of Cercospora sequoiae on Taxodium mucronatum.

D : Stroma of Cercospora sequoiae on Cryptomeria japonica inoculated with Taxodium-isolate.

E : Conidia of Cercospora sequoiae on Cryptomeria japonica inoculated with Taxodium-isolate.

F : Stroma of Cercospora sequoiae on Cryptomeria japonica inoculated with Cryptomeria-isolate.

G : Conidium of Cercospora sequoiae on Cryptomeria japonica inoculated with Cryptomeria-isolate. 


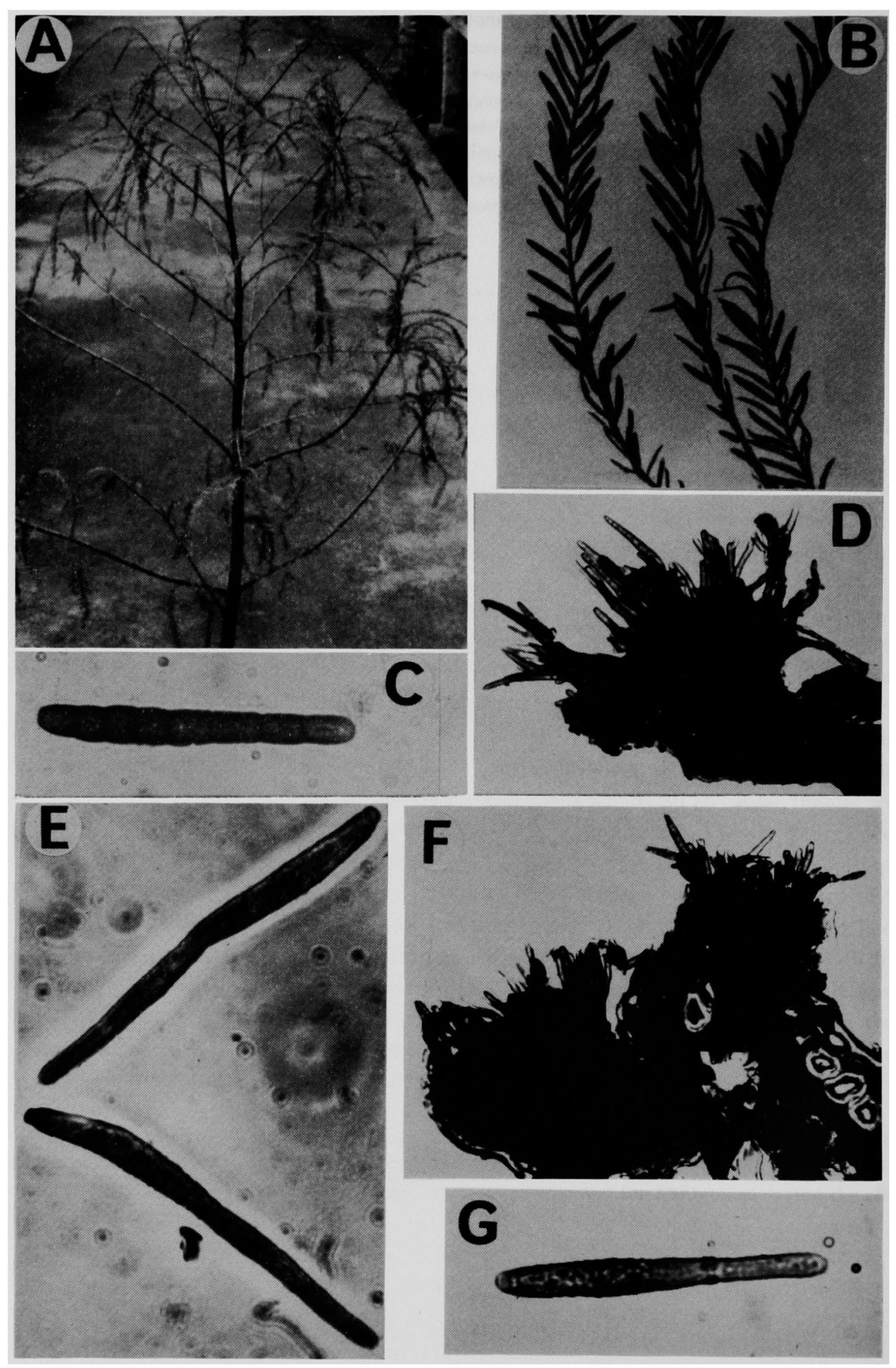

